\title{
A model of co-occurrence: segregation and aggregation patterns in the mycoflora of the crayfish Procambarus clarkii in Lake Trasimeno (central Italy)
}

\author{
Ambrosius J.M. DÖRR, Antonia C. ELIA, Marinella RODOLFI, ${ }^{1}$ Laura GARZOLI, ${ }^{1}$ Anna M. PICCO, ${ }^{1}$ \\ Manuela D'AMEN, ${ }^{2}$ and Massimiliano SCALICI ${ }^{3 *}$
}

Department of Cellular and Environmental Biology, University of Perugia, Via Elce di Sotto, 06123 Perugia, Italy; ${ }^{1}$ Department of Earth Science and Environment, Laboratory of Mycology, University of Pavia, Via San Epifanio 14, 27100 Pavia, Italy; ${ }^{2}$ Department of Environmental Biology, University of Roma Tre, Viale Guglielmo Marconi 446, 00146 Roma, Italy; ${ }^{3}$ Department of Biology, University of Roma Tre, Viale Marconi 446, 00146 Roma, Italy

*Corresponding author: scalici@uniroma3.it

\begin{abstract}
Although attention on crayfish diseases has recently proliferated, the focus is mainly on a single host-parasite relationship rather than analyzing the entire mycoflora, probably due to the fact that (1) some diseases are occasional (pathogens of which are of difficult collection) and (2) economic impact is more relevant in aquaculture (i.e., a controlled environment where only few parasites occur) than in natural conditions. Contrary to this viewpoint, fungal ectoparasites assume a great importance since they are integral components in shaping community, ecosystem structure, and energy flow. Here we described the fungal species co-occurrence patterns (species segregation/aggregation) using null models comparing the occurrence frequencies of ectosymbiots through host individuals with those expected by chance. Non-indigenous crayfish species like Procambarus clarkii allow to observe phenomena of competitive exclusion (segregation) or mutualism (aggregation) amongst fungi. We analyzed the fungal species occurrence on 86 host crayfish monthly collected from June 2007 to June 2008 in the Lake Trasimeno (Central Italy). A total of 29 fungal taxa were detected. Taxa showed a particular fungal assemblage with a great species variation depending on sampling month and crayfish sex, size, and body region. In particular, fungal species showed different occurrence patterns in both richness and segregation/ aggregation. The fungal community shows a non-random structure not in all cases, with the majority of tests indicating segregation, not aggregation of ectosymbiontic species on hosts. The non-random patterns of fungal co-occurrence in some cases suggest that some temporally or spatially variable factors are responsible for the establishment of the mycoflor community assemblage. We also detected temporal differences in fungal co-occurrences patterns. Regarding seasonal samples, the same analyses showed a competitive structure only in the sub-communities found on pleopodal coxae. In addition, analyses considering crayfish dimension evidenced non-random co-occurrence patterns only in crayfish hosts with a cephalothorax length larger than $45 \mathrm{~mm}$. Our results demonstrated that, depending on sampling month and crayfish sex, size, and body region, well structured fungal assemblages on crayfish hosts can alternate with random fungal assemblages. Whenever non-randomness of fungal co-occurrence was detected, it hinted segregation, suggesting the lack of co-evolutive phenomena of mutualism, and favoring a competitive exclusion among the mycoflora species.
\end{abstract}

Key words: aggregation/segregation; mycoflora; fungal ectosymbionts; presence-absence matrix; community temporal variation.

Received: May 2011. Accepted: October 2011.

\section{INTRODUCTION}

Disturbance to ecosystems due to non-indigenous species represents today a well-known biological phenomenon. Alien species may change the native community structure (Keith, and Allardi 1997), alter the relation-ships for both trophic and spatial resources (Leveque 1997), and often carry pests and pathogens (Blanc 1997; Lodge et al. 2000). Among animals, attention is focused on alien crayfish, the most commonly introduced species worldwide (see Holdich et al. 2010), and on the potential disease agents they carry, mainly referring to the fungus-like Aphanomyces astaci Schikora, 1922 (Diéguez-Uribeondo, and Söderhäll 1993). The latter, recorded in Europe since 1860 (Vogt 1999), is responsible for numerous outbreaks of the so-called crayfish plague. From there, it had a dramatic impact on the European native crayfish populations, and its relevance has led to extensive research focused on crayfish pathology in the last 25 years (see Alderman et al. 1987; Diéguez-Uribeondo, and Söderhäll 1993; Edgerton 2002a, b; DiéguezUribeondo et al. 2007; Diéguez-Uribeondo 2009; Kozubíková et al. 2010). The pathogen introduction is one of the reasons why invasive crayfish are responsible for decline or extinction of nearly one third of the world's crayfish populations (Taylor 2002). Furthermore, even human health can be threatened by cray-fish parasites, such as the case of the waterborne out-break of an ulceroglandular tularemia (due to Francisella tularensis biovar palaearctica) associated with the red-swamp cray- 
fish Procambarus clarkii (Girard 1852) fishing (Anda et al. 2001). Although the importance on crayfish diseases has recently proliferated (Hirsch et al. 2008; DiéguezUribeondo 2009), it seems more important focusing studies on a single host-parasite relationship rather than analyzing the entire mycoflora living on the exoskeleton. The absence of detailed studies on the entire ecto-symbiontic mycoflora is probably due to the fact that (1) some diseases are occasional (pathogens of which are of difficult collection), and (2) economic impact is more relevant in cray-fish farming (see Carral et al. 2009) where less parasites occur than in natural populations (DiéguezUribeondo 2009).

Pathogen pollution (sensu Cunningham et al. 2003) can amplify the detrimental effect of endemic pathogens (Kelly et al. 2009) in some cases reducing local biodiversity by eliminating populations of host species (Preston, and Johnson 2010). In addition, this effect can be particularly pronounced when hosts are keystone or dominant species with important functions in an ecosystem (Preston, and Johnson 2010), such as crayfish. The latter are the largest and long-lived invertebrates in temperate areas (see Scalici et al. 2008, 2009), playing a major role in the community structure (Usio, and Townsend 2004), being keystone consumers (e.g., Whitledge, and Rabeni 1997; Scalici, and Gibertini 2007) and prey of several vertebrates (e.g., Blake 1995; Slater, and Rayner 1993; Rodríguez et al. 2005).

To date, attempts for studying crayfish pathogens are mainly concentrated on single species, and studies on the mycoflora assemblage seem to be restricted to decomposers. Freshwater fungi have an important position in inland water ecosystems due to their role in decomposition and as nutritional resource to animals in food webs (Ho et al. 2001; Cai et al. 2006). Until today, documentation of changes in fungal community represents a challenging research project little attempted (see Hu et al. 2010). Even if fungal ectoparasite assemblage seems to receive little attention in scientific studies, these associations assume a great importance since they are fundamental components in shaping community, ecosystem structure and energy flow (Mitchell 2003; Kuris et al. 2008).

Here we describe the co-occurrence patterns of ectoparasite fungi in terms of segregation and/or aggregation. We used a null model approach (see Gotelli 2000) to compare occurrence frequencies of parasites through host individuals with those expected by chance, although it cannot indicate the mechanism responsible for non-randomness (Rohde 2005). Although some aspects of the algorithms suggested by Gotelli, and Entsminger (2009) and Gotelli (2000) have been criticized (Sanderson 2000; Hausdorf, and Hennig 2007), their good statistical properties have been demonstrated (Gotelli 2000; Gotelli, and McCabe 2002), leading to a substantial increase in para- site community studies in the last decade (see Poulin 2007).

Our study is aimed to describe eventual potential interactions among fungal species carried by crayfish, and here we report the results of a mycological investigation on P. clarkii captured in the Lake Trasimeno (Central Italy), where this species acclimated about ten years ago (Dörr et al. 2001, 2006). In this context, the use of a nonindigenous species such as the red swamp crayfish has the advantage to observe phenomena of either segregation (interpreted as the result of a competitive exclusion among species) or aggregation (interpreted as mutualism) between fungi colonizing the cray-fish exoskeleton. If species co-occur less frequently than expected by chance the assemblage is structured segregatively, mainly due to competition or different micro-habitat preferences. When species co-occur more often than expected by chance the assemblage is structured aggregatively, throughout interspecific facilitation or shared preferences (Krasnov et al. 2006). We compared frequencies of co-occurrences of parasite species or genera across host individuals (i.e., "sites") with those expected by chance, i.e. derived from randomly assembled species by site matrices.

Following the hypothesis of Gothelli, and Rhode (2002) and Rohde (2005), non-randomness in organization of a parasite community is related to the level of vagility of their hosts: animals with little vagility and/or small individual or population size live in largely empty niche space and are less subject to structuring mechanisms (competition, facilitation, heterogeneity in infection) than animals that are large or live in large populations with much vagility and are closer to saturation (Rohde 1980). Due to the high mobility of P. clarkii, a non random pattern in the distribution of fungal ecto-symbionts is expected.

\section{MATERIALS AND METHODS}

We analyzed the fungal species occurrence on a total of 86 host crayfish monthly collected from June 2007 to June 2008 in Lake Trasimeno (central Italy). Specimens were sexed, measured and brought immediately to the laboratory. Ectoparasite fungal taxa were identified processing three exoskeletal portions per specimen according to the Alderman, and Polglase (1986) protocol, favourable to the growth of both pathogens and saprophytes fungi which feed on crayfish. In particular, three $2-5 \mathrm{~mm} 2 \mathrm{sam}-$ ples were removed from abdominal tergitae (AbT), sternitae (AbS) and pleopodal coxae (PIC). Cuticle portions were placed on Petri plates containing the medium GOYA (Glucose Oxolynic Yeast extract Agar, medium composition: $12 \mathrm{~g}$ agar, $1 \mathrm{~g}$ yeast extract, $5 \mathrm{~g}$ glucose, $10 \mathrm{mg}$ oxolynic acid and $1000 \mathrm{~mL}$ distilled water). Samples were then incubated at $25^{\circ} \mathrm{C}$ and weekly observed by means of stereomicroscope (50x) up to 4 weeks. Each microfungal structure was directly identified or transferred to an ap- 
propriate medium for identification. Using the generic medium PDA (Potato Dextrose Agar, medium composition: $200 \mathrm{~g}$ potato, $20 \mathrm{~g}$ dextrose, $15 \mathrm{~g}$ agar and $1000 \mathrm{~mL}$ distilled water) for microfungi, all microfungal strains were finally collected as pure cultures.

The collected sample was composed only by adult crayfish, depending on the cephalothorax length (see Scalici, and Gherardi 2007). Hosts were divided per sex, size, body parts (AbT, AbS, PlC), and season (spring, summer, autumn, and winter) analyzing a total of 108 matrices, in order to observe whether the latter variables can affect the fungal assemblage. As size depends on cephalothorax length (CL), we used five size classes at an interval of $5 \mathrm{~mm} \mathrm{CL}$, according to Scalici et al. (2009): $30<\mathrm{CL}<34 \mathrm{~mm} ; 35<\mathrm{CL}<39 \mathrm{~mm} ; 40<\mathrm{CL}<44 \mathrm{~mm} ; 45<\mathrm{CL}<$ $49 \mathrm{~mm}$; CL $>50 \mathrm{~mm}$ ).

To perform the null model approach, data were organized in a presence-absence (1-0) matrix, fundamental in ecological and biogeographic studies (McCoy, and Heck 1987), where each row represents a crayfish whilst each column a parasite species. Using presence-absence data provides less uncertainty in measuring occurrence rather than in measuring abundance, and does not mask non-random community patterns (see Haukisalmi, and Henttonen 1993).

We applied two indices to quantify patterns of mycoflora community structure: the C-score (Stone, and Roberts 1990) and the variance ratio (V-ratio; Schluter 1984). Each index is a single number that measures patterns for an entire presence/absence matrix. We used both indices based on two different matrix structures (namely average co-occurrence and average covariance, respectively) because they have shown to be statistically powerful and robust to minor changes in community structure (Gotelli 2000). Details of statistical properties and performance of the metrics can be found in Gotelli, and Rohde (2002), Krasnov et al. (2006, 2010), and references therein. Briefly, the $\mathrm{C}$-score quantifies the degree of species co-occurrence and is calculated as the average number of checkerboard units that are found for each pair of species. The V-ratio is the ratio between the variance in species richness and the sum of the variance in species occurrence. When the value of the ratio equals 1 species are distributed independently. It is smaller or greater than 1 in the case of negative or positive covariance between species pairs, respectively (Gotelli 2000). The latter metric was calculated both including and excluding the uninfested crayfish (empty sites; WI=with empty sites; $\mathrm{WO}=$ without empty sites). For each matrix we contrasted the observed index $(\mathrm{O})$ with that simulated by $3 \times 10^{4}$ random Monte Carlo permutations [i.e., expected (E) by chance] in EcoSim 7.0 (Gotelli, and Entsminger 2001). This number of permutations ensures that algorithm biases are avoided (Lehsten, and Harmand 2006). A C-score value smaller than expected by chance $(\mathrm{O}<\mathrm{E})$ means aggregation of parasite taxa. In this case we expect that the species combinations and V-ratio are larger than expected by chance $(\mathrm{O}>\mathrm{E})$. On the contrary, when fungal species show segregation, we expect the $\mathrm{C}$-score to be larger and the V-ratio to be smaller than expected by chance $(\mathrm{O}>\mathrm{E})$, (Gotelli, and Rohde 2002). Non-random differences were assumed when $\mathrm{P} \mathrm{O} \geq \mathrm{E}$ or $\mathrm{P} \mathrm{O}<\mathrm{E} \leq 0.05$ (Gotelli, and Graves 1996). We used two null algorithms for each comparison: fixed-fixed $(f f)$ and fixed-equiprobable $(f e)$. The ff algorithm maintains the differences among hosts in the number of parasite species. This model cannot be used for V-ratio because the latter is determined by marginal totals of the matrix rather than by species co-occurrence pattern (Gotelli 2000). Differently, the $f e$ algorithm does not constrain the number of species that can be harbored by a host. This last model suggests no differences in the probability to support a particular number of fungal species amongst host individuals.

\section{RESULTS}

A total of 29 filamentous fungal taxa were detected (Fig. 1). Yeasts were also recorded. Taxa showed a particular fungal assemblage with a great species variation depending on sampling month and crayfish sex, size, and body region. In particular, fungal species showed different occurrence patterns in both richness and segregation/aggregation.

Examples of the fungal species occurrence are given here. Some species occurred only on a particular body region such as Aspergillus niger recorded on the abdominal tergitae, while others on the entire abdomen of one sex, like Fusarium proliferatum recorded only on females. We observed both abundant (Phoma glomerata) and very rare species (Acremonium chrysogenum on female pleopodal coxae in November 2007, and on male abdominal tergitae in June 2008). Moreover, there were species co-occurring in both sexes (such as Fusarium verticillioides in $\mathrm{AbT}$ and PlC in January 2008) and segregated species. Segregations may depend on body region (such as Aspergillus niger in abdominal tergitae vs Graphium sp. in pleopodal coxae in October 2007 on females) and sampling month (such as Cladosporium cladosporioides and Clonostachys rosea never co-occurring on males).

We observed a general accordance with the V-ratio results when uninfested hosts were included or excluded from the analyses, while considering the $\mathrm{C}$-score non-random community structures were evidenced mainly by the $f e$ model (i.e., among hosts no differences for the number of fungal species carried on the exoskeleton). The $\mathrm{C}$-score and V-ratio values are reported in the Tabs 1 and 2. Both indices are calculated with the $f f$ (among hosts, differences for the number of parasite species) and fe (among hosts, no differences for the number of fungal species carried on 

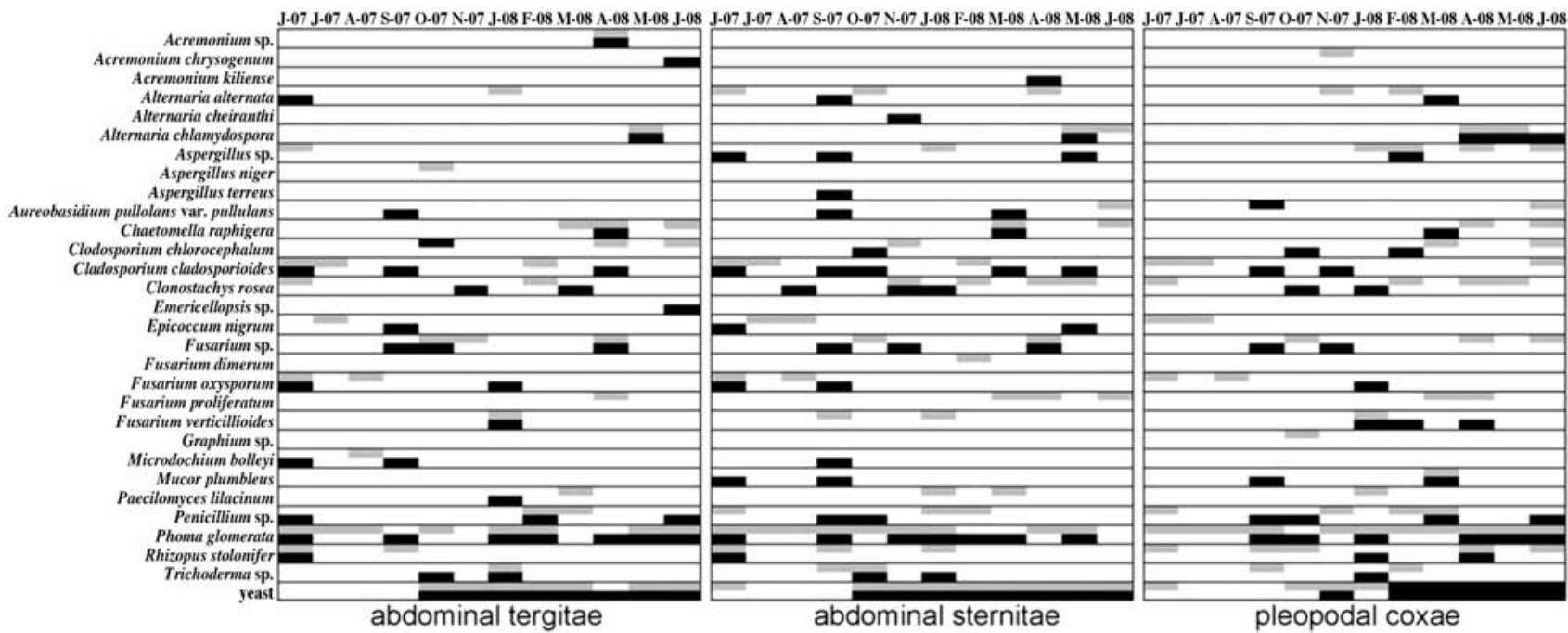

Fig. 1. Fungal species occurrence on the three investigated crayfish body regions of females (gray) and males (black) collected monthly from June 2007 to June 2008.

the exoskeleton) null model algorithms, and including and excluding the uninfested crayfish, respectively. Overall our results indicate that the fungal community is non-randomly structured, with the majority of tests indicating segregation, not aggregation of parasite species on hosts. Considering the overall dataset, in the $f e$ model the $\mathrm{C}$ score showed that there is much less co-occurrence in the fungal matrix than expected by chance $(\mathrm{P}(\mathrm{O}>\mathrm{E})<0.05)$, and this is confirmed by the V-ratio tests both including and excluding empty sites $(\mathrm{P}(\mathrm{O}<\mathrm{E})<0.05)$. This competitive structure was evidenced by the $\mathrm{C}$-score also considering separately male and female hosts, while the V-ratio metric evidenced only a non-random structure in communities living on female crayfish.

We detected temporal differences in fungal co-occurrences patterns: competitive structure was evidenced by the $f e$ model mainly during spring considering the "all body community" (both by C-score and V-ratio metrics). Notably, C-score results from the ff model algorithm evidenced a structured community only in the samples collected in autumn $(\mathrm{P} \quad(\mathrm{O}<\mathrm{E})<0.05)$ and winter $(\mathrm{P}$ $(\mathrm{O}>\mathrm{E})<0.05)$. If we consider the parasites sub-communities of different crayfish body regions, regardless of host $\mathrm{CL}$, both C-score (with $f f$ and $f e$ algorithm) and V-ratio (with WI and WO) indicated species segregation for abdominal tergitae, pleopodal coxae, while no significant differences were detected for the body region abdominal sternitae. Regarding seasonal samples, the same analyses showed a competitive structure only in the sub-communities found on pleopodal coxae. In addition, analyses considering crayfish dimension evidenced non-random co-occurrence patterns only in crayfish hosts with a cephalothorax length larger than $45 \mathrm{~mm}$.

\section{DISCUSSION}

The results of the present study highlight two particular aspects until today poorly treated: 1) the co-occurrence pattern of the freshwater ectoparasite fungal species (with relevant effects in the field of ecology and farming); 2) the use of introduced species to observe colonization dynamics (of fungal species in this study) in a new habitat. Concerning the latter point, two different types of colonization emerged: 1) the case of Fusarium spp. on $P$. clarkii, a new "microfungus-crayfish", interaction never detected before; 2) the fungal species introduction in a new environment, such as $P$. glomerata in Lake Trasimeno (see Dörr et al. 2011). The Fusarium-P. clarkii interaction deserves special attention and the concrete possibility of a negative impact related to the spread of the fungus really may exist. Due to its ability to grow on a wide range of substrates and its efficient mechanisms for dispersal (Burgess 1981), Fusarium shows a widespread distribution and a relevant role in nature. It can be also the origin of a huge variety of diseases on a wide range of hosts, being one of the most damaging plant pathogen, a toxin producer and one of the emerging causes of opportunistic mycoses to animal and human. To this regard, as reviewed by Jain et al. (2011), up to now 15 species of Fusarium have been reported as etiological agents of infection, always originated from animal or plant source in nature. In Italy, the number of disseminated infections has greatly increased and $F$. oxysporum and $F$. verticillioides, species detected in our survey, result among the most prevalent species involved in human mycoses (Tortorano et al. 2008).

Although investigations on the mycoflora community have already been conducted in the past, studies on fresh- 
Tab. 1. Summary of the null model analyses of fungal species co-occurrence through seasons for the entire host assemblage and both sexes using $f f$ and $f e$ null model algorithms: $\mathrm{O}<\mathrm{E}=$ number of samples for which the observed value of the index was significantly less than expected by chance $(P<0.05)$; $\mathrm{O}>\mathrm{E}=$ number of samples for which the observed value of the index was significantly greater than the expected by chance $(P<0.05)$. Significant probably values are reported in italics and bold. Crayfish number are reported in parentheses. Acronyms in alphabetical order: $\mathrm{A}=$ aggregation; $\mathrm{E}=$ expected; $\mathrm{fe}=$ fixed-equiprobable algorithm; $f f=$ fixed-fixed algorithm; $\mathrm{O}=\mathrm{ob}-$ served; $\mathrm{S}=$ segregation; $\mathrm{WI}=$ with empty sites; $\mathrm{WO}=$ without empty sites.

\begin{tabular}{|c|c|c|c|c|c|c|c|c|c|c|}
\hline \multirow[b]{2}{*}{ total } & & \multicolumn{3}{|c|}{ total body } & \multicolumn{3}{|c|}{ abdominal tergitae } & \multicolumn{3}{|c|}{ pleopodal coxae } \\
\hline & & tot (87) & $\mathrm{f}(47)$ & m (40) & tot (87) & $\mathrm{f}(47)$ & m (40) & tot $(87)$ & $\mathrm{f}(47)$ & $\mathrm{m}(40)$ \\
\hline & C-score & 94.79085 & 25.89542 & 20.1634 & 26.0719 & 7.19608 & 7.075 & 34.8366 & 9.65359 & 8.19118 \\
\hline fe & $P(\mathrm{O}>\mathrm{E})$ & 0.04803 & 0.03237 & 0.01033 & 0.0941 & 0.2342 & 0.17117 & 0.016 & 0.34683 & 0.00207 \\
\hline \multirow[t]{2}{*}{ spring } & & tot (27) & $\mathrm{f}(16)$ & $\mathrm{m}(11)$ & tot (27) & $\mathrm{f}(16)$ & $\mathrm{m}(11)$ & tot (27) & $\mathrm{f}(16)$ & $\mathrm{m}(11)$ \\
\hline & C-score & 13.1 & 5.92308 & 2.41758 & 4.92727 & 3.6428 & 1.6 & 7.666667 & 3.71212 & 2.25 \\
\hline fe & $P(\mathrm{O}>\mathrm{E})$ & 0.0009 & 0.02253 & 0.04547 & 0.23547 & 0.6045 & 0.1738 & 0.00093 & 0.0035 & 0.1429 \\
\hline \multirow[t]{2}{*}{ summer } & & tot (35) & $\mathrm{f}(19)$ & m (16) & tot (35) & $f(19)$ & m (16) & tot (35) & $\mathrm{f}(19)$ & m (16) \\
\hline & C-score & 12.98693 & 2.98693 & 6.32051 & 7.95604 & 2.56 & 4.46667 & 6.46667 & 2.303 & 5.6071 \\
\hline$f f$ & $P(\mathrm{O}>\mathrm{E})$ & 0.60197 & 0.38047 & 0.77703 & 0.82747 & 0.7265 & 0.83353 & 0.34117 & 0.7675 & 0.03343 \\
\hline fe & $P(\mathrm{O}>\mathrm{E})$ & 0.41887 & 0.4856 & 0.55157 & 0.38843 & 0.81887 & 0.1206 & 0.29463 & 0.84237 & 0.02867 \\
\hline \multirow[t]{2}{*}{ autumn } & & tot $(9)$ & $f(4)$ & $\mathrm{m}(5)$ & tot $(9)$ & $\mathrm{f}(4)$ & $\mathrm{m}(5)$ & tot (9) & $f(4)$ & m (5) \\
\hline & C-score & 2.48889 & - & - & - & - & - & - & - & - \\
\hline$f f$ & $P(\mathrm{O}>\mathrm{E})$ & 0.03467 & - & - & - & - & - & - & - & - \\
\hline \multirow[t]{3}{*}{ winter } & & tot (16) & $f(8)$ & $\mathrm{m}(8)$ & tot $(16)$ & $\mathrm{f}(8)$ & $\mathrm{m}(8)$ & tot (16) & $f(8)$ & $\mathrm{m}(8)$ \\
\hline & C-score & 4.34848 & 2.44444 & 1.64286 & 5.53333 & - & - & 3.17778 & 1.8 & 1.321 \\
\hline & $P(\mathrm{O}>\mathrm{E})$ & 0.14973 & 0.05717 & 0.75177 & 0.1648 & - & - & 0.17917 & 0.62847 & 0.04363 \\
\hline \multirow[t]{2}{*}{ total } & & tot $(87)$ & $\mathrm{f}(47)$ & $\mathrm{m}(40)$ & tot $(87)$ & $\mathrm{f}(47)$ & m (40) & tot $(87)$ & $\mathrm{f}(47)$ & $\mathrm{m}(40)$ \\
\hline & V-ratio & 0.66707 & 0.61888 & 0.73927 & 0.73323 & 0.83273 & 0.64418 & 0.63138 & 0.81726 & 0.42142 \\
\hline \multirow{2}{*}{ WI } & $P(\mathrm{O}>\mathrm{E})$ & 0.00663 & 0.02073 & 0.1211 & 0.0269 & 0.23917 & 0.0417 & 0.00223 & 0.2062 & 0.00047 \\
\hline & V-ratio & 0.58497 & 0.54179 & 0.64675 & 0.40522 & 0.50708 & 0.29852 & 0.44187 & 0.55845 & 0.29271 \\
\hline WO & $P(\mathrm{O}>\mathrm{E})$ & 0.00673 & 0.01853 & 0.10367 & 0.12377 & 0.55347 & 0.0392 & 0.05717 & 0.39483 & 0.00787 \\
\hline \multirow[t]{2}{*}{ spring } & & tot (27) & $\mathrm{f}(16)$ & m (11) & tot (27) & $f(16)$ & m (11) & tot (27) & $\mathrm{f}(16)$ & m (11) \\
\hline & V-ratio & 0.35675 & 0.49105 & 0.18769 & 0.92812 & 0.9321 & 0.53 & 0.37813 & 0.35952 & 0.448 \\
\hline \multirow[t]{2}{*}{ WI } & $P(\mathrm{O}>\mathrm{E})$ & 0.00113 & 0.06407 & 0.0057 & 0.4939 & 0.68273 & 0.16817 & 0.0017 & 0.0155 & 0.113 \\
\hline & V-ratio & 0.35675 & 0.49105 & 0.18692 & 0.47642 & 0.48 & 0.38596 & 0.37813 & 0.35952 & 0.448 \\
\hline WO & $P(\mathrm{O}>\mathrm{E})$ & 0.00223 & 0.10057 & 0.00687 & 0.74447 & 0.6549 & 0.4825 & 0.03907 & 0.09807 & 0.31313 \\
\hline \multirow[t]{2}{*}{ winter } & & tot $(16)$ & $f(8)$ & $\mathrm{m}(8)$ & tot (16) & $\mathrm{f}(8)$ & m (8) & tot (16) & $\mathrm{f}(8)$ & m (8) \\
\hline & V-ratio & 0.84946 & 0.66667 & 1.12195 & 0.549 & - & - & 0.6803 & 1.0001 & 0.437 \\
\hline WI & $P(\mathrm{O}>\mathrm{E})$ & 0.41583 & 0.33933 & 0.71897 & 0.1069 & - & - & 0.22773 & 0.6575 & 0.032 \\
\hline
\end{tabular}

water ectoparasite mycoflora were not exhaustively treated, to the best of our knowledge. In our study, segregation was interpreted as the result of competitive exclusion among species, while aggregation as the effect of mutualism. Such a community is expected to display positive co-occurrence and be aggregatively structured (Diamond 1975; Gotelli, and Rohde 2002). If species in a community co-occur less frequently than expected by chance, this may be due to interspecific competition (Diamond 1975) or differential preferences (Pielou, and Pielou 1968). Such a community is expected to display negative co-occurrence and be segregatively structured (Diamond 1975; Gotelli, and Rohde 2002). In particular, potential mechanisms producing a pattern can be inferred only after establishment of whether empirical pattern deviates from those expected under random processes (Connor, and Simberloff 1979; Hausdorf, and Hennig 2007).

The non-random pattern of fungal co-occurrence found in some cases in this study suggests that some tem- porally or spatially variable factors are responsible for the expression of community structure. Although interspecific competition is important in several parasite assemblages, our null model analyses reinforce the idea that the crayfish mycoflora assemblage seemed unstructured by species interactions (species always segregate avoiding direct interactions). In fact, results of this study demonstrated that (a) fungal assemblages on crayfish hosts were structured at some times, whereas they appeared to be randomly assembled at other times, and (b) whenever non-randomness of fungal co-occurrences was detected, it suggested segregation. Additionally, most parasite species occurred in a few host individuals, while most hosts had only a few parasites.

Our results showed fluctuating fungal colonization depending on season, and crayfish size and sex. In particular, in all the significant cases fungal species appeared to show segregation. The fungal species segregation due to crayfish size and sex may rise from the different exoskele- 
Tab. 2. Summary of the null model analyses for fungal species co-occurrence among size classes (obtained using $5 \mathrm{~mm}$ intervals of the cephalothorax length) for the entire host assemblage and both sexes using $\mathrm{ff}$ and fe null model algorithms: $\mathrm{O}<\mathrm{E}=$ number of samples for which the observed value of the index was significantly less than the expected by chance $(P<0.05) ; \mathrm{O}>\mathrm{E}=$ number of samples for which the observed value of the index was significantly greater than the expected by chance $(P<0.05)$. Significant probably values are reported in italics and bold. Between parentheses the crayfish number used in the analysis. Acronyms in alphabetical order: AbT=abdominal tergitae ; $\mathrm{CTL}=$ cephalothorax length; $\mathrm{E}=$ expected; $f e=$ fixed-equiprobable algorithm; $f f=$ fixed-fixed algorithm; $\mathrm{O}=$ observed; $\mathrm{PlC}=$ pleopodal coxae; $\mathrm{S}=$ segregation; $\mathrm{WI}=$ with empty sites; $\mathrm{WO}=$ without empty sites.

\begin{tabular}{|c|c|c|c|c|c|c|c|}
\hline \multirow[b]{2}{*}{ total body } & & \multicolumn{3}{|c|}{$45<\mathrm{CTL}<49$} & \multicolumn{3}{|c|}{$\mathrm{CTL}>50$} \\
\hline & & tot $(17)$ & $\mathrm{f}(10)$ & $\mathrm{m}(7)$ & tot (42) & $f(21)$ & $\mathrm{m}(20)$ \\
\hline & C-score & 4.05714 & 2.81818 & 1.37778 & 23.13725 & 6.36601 & 5.6 \\
\hline$f e$ & $P(\mathrm{O}>\mathrm{E})$ & 0.05627 & 0.02757 & 0.33307 & 0.05467 & 0.048 & 0.03117 \\
\hline \multirow[t]{2}{*}{ Abt } & & tot $(17)$ & $\mathrm{f}(10)$ & $\mathrm{m}(7)$ & tot (42) & $f(21)$ & $\mathrm{m}(20)$ \\
\hline & C-score & 3.89286 & 4 & 1.33333 & 8.5416 & 3.538 & 2.6435 \\
\hline$f e$ & $P(\mathrm{O}>\mathrm{E})$ & 0.03907 & 0.0866 & 0.167 & 0.18223 & 0.2941 & 0.28323 \\
\hline \multirow[t]{2}{*}{$\mathrm{PlC}$} & & tot $(17)$ & $\mathrm{f}(10)$ & $\mathrm{m}(7)$ & tot (42) & $f(21)$ & $\mathrm{m}(20)$ \\
\hline & C-score & 2.89744 & 2.21429 & 1.333 & 9.45 & 2.9833 & 4.0888 \\
\hline fe & $P(\mathrm{O}>\mathrm{E})$ & 0.1144 & 0.2146 & 0.20317 & 0.0412 & 0.27657 & 0.04603 \\
\hline \multirow[t]{2}{*}{ total body } & & tot $(17)$ & $\mathrm{f}(10)$ & $\mathrm{m}(7)$ & tot $(42)$ & $f(21)$ & $\mathrm{m}(20)$ \\
\hline & V-ratio & 0.32218 & 0.2716 & 0.37838 & 0.59407 & 0.57206 & 0.69406 \\
\hline \multirow[t]{2}{*}{ WI } & $P(\mathrm{O}>\mathrm{E})$ & 0.0072 & 0.0279 & 0.16147 & 0.0181 & 0.07337 & 0.09503 \\
\hline & V-ratio & 0.32218 & 0.2716 & 0.37838 & 0.41026 & 0.38005 & 0.55006 \\
\hline WO & $P(\mathrm{O}>\mathrm{E})$ & 0.01657 & 0.04797 & 0.2972 & 0.00097 & 0.0091 & 0.1708 \\
\hline \multirow[t]{2}{*}{$\mathrm{AbT}$} & & tot $(17)$ & $f(10)$ & $\mathrm{m}(7)$ & tot (42) & $f(21)$ & $\mathrm{m}(20)$ \\
\hline & V-ratio & 0.483 & 0.432 & 0.48 & 0.8034 & 0.9678 & 0.65947 \\
\hline \multirow[t]{2}{*}{ WI } & $P(\mathrm{O}>\mathrm{E})$ & 0.00983 & 0.12007 & 0.24523 & 0.20483 & 0.5566 & 0.16143 \\
\hline & V-ratio & 0.21053 & 0.1428 & 0.2195 & 0.4561 & 0.6 & 0.299 \\
\hline WO & $P(\mathrm{O}>\mathrm{E})$ & 0.02933 & 0.1258 & 0.32943 & 0.32017 & 0.68317 & 0.12873 \\
\hline \multirow[t]{2}{*}{$\mathrm{PlC}$} & & tot $(17)$ & $\mathrm{f}(10)$ & $m(7)$ & tot (42) & $\mathrm{f}(21)$ & $\mathrm{m}(20)$ \\
\hline & V-ratio & 0.3954 & 0.40741 & 0.36364 & 0.6 & 0.70819 & 0.4223 \\
\hline \multirow[t]{2}{*}{ WI } & $P(\mathrm{O}>\mathrm{E})$ & 0.02037 & 0.09533 & 0.15653 & 0.01957 & 0.2006 & 0.01687 \\
\hline & V-ratio & 0.395 & 0.40741 & 0.36364 & 0.3678 & 0.3826 & 0.2429 \\
\hline WO & $P(\mathrm{O}>\mathrm{E})$ & 0.2039 & 0.42957 & 0.27273 & 0.0381 & 0.09343 & 0.03453 \\
\hline
\end{tabular}

ton composition between sexes and size classes (although ontogenetic variation in the exo-skeleton composition was never detected before), while the fungal segregation due to season may rise either from chorology of each fungal species or from chance, beyond the competitive aspects. However, synergy between both previous cited phenomena cannot be excluded.

A particular result rises from the affinity of some species for a particular body region. The most evident result is the absence of non-random fungal assemblage in the abdominal sternitae, while the remanent two investigated body regions seemed to show alternatively random and non-random assemblages. Moreover, some species occurring on the abdominal part, singularly colonized the pleo-podal coxae but not the abdominal sternitae.

The fact that fungal species were consistently segregated (and not aggregated) on their hosts seems to support the conclusions that changes in fungal assemblage during the study period are dominated by negative interspecific interactions, showing competitively structured parasite communities just previously described for other taxa (in example Patrick 1991; Combes 2001).

A reason for the observed consistency in the pattern of community organization among parasites may be due to differences in various life history traits of taxa as well as among hosts harboring them (Gotelli, and McCabe 2002; Rohde 2005). An explanation of the observed pattern in the fungal co-occurrence may regard the heterogeneity of spatial behavior of host individuals. The increase of density in crayfish populations often results in a surplus of dispersing individuals that do not possess permanent burrows (Gherardi 2002). Procambarus clarkii can also walk up to $4 \mathrm{~km}$ per day on land (Gherardi et al. 2002), and consequently the possibility of spreading diseases by this species could be an additional negative element linked to its presence on the territory. This host heterogeneity can also be explained by the tendency of the fungal communities structure to be expressed better under high host population density, since the number of dispersing hosts increases with population growth (although data on this topic are lacking in literature). Additionally, effects of host's vagility on the non-randomness 
of ectosymbiontic communities may be due also to the occurrence of temporary ectosymbionts, such as Chaetomella raphigera, Paecilomyces lilacinus and Trichoderma spp. collected in the present study. In fact, studying blood-sucking insects, Lehane (2005) stated that temporary parasites are free-living organisms which visit the host for a time enough to refresh oneself (e.g., ixodid ticks and mosquitoes), while periodic ectoparasites spend a longer time than is required both on hosts to eat and also off-host (e.g., most fleas and mesostigmate mites). Being the parasite vagility mediated by the dispersal capability of host species, temporary ectoparasites can be considered more vagile than periodic ectoparasites. If hosts are highly mobile, chances for ectoparasite exchange between individuals are high, making the expected non-randomness easily found in communities of temporary ectoparasites rather than in those of periodic ectoparasites (Lehane 2005).

\section{CONCLUSIONS}

These analyses revealed little evidences for non-random community patterns, reinforcing the authors idea that these parasites live in largely structured assemblages. A variety of patterns of non-randomness has been suggested (Diamond 1975; Hanski 1982; Patterson, and Atmar 1986; Fox, and Brown 1993). The relationship between population size and the detection of non-randomness in these communities suggests that community structure can vary temporally due to temporally variable population size (Vidal-Martinez, and Poulin 2003). Conclusions expressed above suggest that there is potential for further investigations in this field, when taking into account the immune defense of freshwater crayfish as well as the interaction between endo- and ectoparasites colonizing them.

\section{REFERENCES}

Alderman DJ, and Polglase JL. 1986. Aphanomyces astaci: isolation and culture. J. Fish. Dis. 9: 367-379.

Alderman DJ, Polglase JL, and Frayling M. 1987. Aphanomyces astaci pathogenicity under laboratory and field conditions. J. Fish Dis. 10: 385-393.

Anda P, del Pozo JS, Diáz Garciá JM, Escudero R, Garciá Peña FJ, López Velasco MC, Sellek RE, Jiménez Chillarón MR, Sánchez Serrano LP, and Martínez Navarro JF. 2001. Waterborne outbreak of Tularemia associated with crayfish fishing. Emerg. Infect. Dis. 7: 575-582.

Blake MA. 1995. The vulnerability of juvenile signal crayfish to perch and eel predation. Freshwater Biol. 33: 233-244.

Blanc G. 1997. L'introdution des agents pathogènes dans les écosistèmes aquatiques: aspects théoriques et réalités. Knowl. Manag. Aquat. Ec. (BFPP-Connaiss. Gest. P.), 344345: 489-514.

Burgess LW. 1981. General Ecology of the Fusaria. In: P.E. Nelson, T.A. Toussoun, and R.J. Cook (Eds), Fusarium: Dis- eases, Biology and Taxonomy. Pennsylvania State University Press, Philadelphia: 225-235.

Cai L, Ji KF, and Hyde KD. 2006. Variation between fresh-water and terrestrial fungal communities on decaying bamboo culms. Antonie van Leeuwenhoek 89: 293-301.

Carral JM, González A, Celada JD, Sáez-Royuela M, Melendre PM, González R, and García V. 2009. Antifungal treatments in artificial incubation of crayfish eggs (Pacifastacus leniusculus, Astacidae): searching for alternatives to formaldehyde. Knowl. Manag. Aquat. Ec. 394-395: 16.

Combes C. 2001. Parasitism. The ecology and evolution of intimate interactions. University Chicago Press: 727 pp.

Connor EF, and Simberloff DS. 1979. The assembly of species communities: chance or competition? Ecology 60: 11321140 .

Cunningham AA, Daszak P, and Rodríguez JP. 2003. Pathogen pollution: defining a parasitological threat to biodiversity conservation. J. Parasitol. 89: S78-S83.

Diamond JM. 1975. Assembly of species communities: chance or competition. In: M.L. Cody, and J.M. Diamond (Eds), Ecology and evolution of communities. Belknap Press of Harvard University Press: 342-444.

Diéguez-Uribeondo J. 2009. Current techniques, approaches and knowledge in diagnosis of crayfish plague and other crayfish diseases. Knowl. Manag. Aquat. Ec. 394-395: 1-3.

Diéguez-Uribeondo J, Fregeneda-Grandes JM, Cerenius L, Pérez-Iniesta E, Aller-Gancedo JM, Tellerí MT, Söderhäll K, and Martín MP. 2007. Re-evaluation of the enigmatic species complex Saprolegnia diclina-Saprolegnia parasitica based on morphological, physiological and molecular data. Fungal. Gen. Biol. 44: 585-601.

Diéguez-Uribeondo J, and Söderhäll K. 1993. Procambarus clarkii Girard as a vector for the crayfish plague fungus, Aphanomyces astaci. Aquac. Freshw. Manag. 24: 761-765.

Dörr AJM, Pedicillo G, and Lorenzoni M. 2001. Prima segnalazione in Umbria di Procambarus clarkii (Girard), Orconectes limosus (Rafinesque) e Astacus leptodactylus Eschscholtz (Crustacea Decapoda). Riv. Idrobiol. 40: 2-3.

Dörr, A.J.M., G. La Porta, G. Pedicillo, and M. Lorenzoni. 2006. Biology of Procambarus clarkii (Girard, 1852) in Lake Trasimeno. Knowl. Manag. Aquat. Ec. (BFPP-Connaiss. Gest. P.), 380-381: 1155-1168.

Dörr AJM, Rodolfi M, Scalici M, Elia AC, Garzoli L, and Picco AM. (2011). The new inland water threat Phoma glomerata in the Italian inland waters. J. Nat. Conserv.: (in press).

Edgerton BF. 2002a. A review of international biosecurity policy development in relation to movements of freshwater crayfish. Knowl. Manag. Aquat. Ec. (BFPP-Connaiss. Gest. P.), 367: 805-812.

Edgerton BF, 2002b. Hazard analysis of exotic pathogens of potential threat to European freshwater crayfish. Knowl. Manag. Aquat. Ec. (BFPP-Connaiss. Gest. P.), 367: 813-820.

Fox BJ, and Brown JH. 1993. Assembly rules for the functional groups in North American desert rodent communities. Oikos 67: 358-370.

Gherardi F. 2002. Behaviour. In: D.M. Holdich (Ed.), Biology of freshwater crayfish. Blackwell Science, Oxford: 258-290.

Gherardi F, Tricarico E, and Ilhéu M. 2002. Movements patterns of an invasive crayfish, Procambarus clarkii, in a temporary stream of southern Portugal. Ethol. Ecol. Evol. 14: 183-197. 
Gotelli NJ. 2000. Null model analysis of species co-occurrence patterns. Ecology 81: 2606-2621.

Gotelli NJ, and Entsminger GL. 2001. Swap and fill algorithms in null model analysis: rethinking the Knight's Tour. Oecologia 129: 281-291.

Gotelli NJ, and Entsminger GL. 2009. EcoSim: null models software for ecology. Ver. 7. Acquired Intelligence Inc. and Kesey-Bear, http://garyentsminger.com/ecosim.htm

Gotelli NJ, and Graves GC. 1996. Null Models in Ecology. Washington, DC, Smithsonian Institution Press: 357 pp.

Gotelli NJ, and McCabe DJ. 2002. Species co-occurrence: a meta-analysis of J.M. Diamond's assembly rules model. Ecology 83: 2091-2096.

Gotelli NJ, and Rohde K. 2002. Co-occurrence of ectoparasites of marine fishes: a null model analysis. Ecol. Lett. 5: 86-94.

Hanski I. 1982. Communities of bumblebees: testing the coresatellite hypothesis. Ann. Zool. Fen. 19: 65-73.

Haukisalmi V, and Henttonen H. 1993. Coexistence in helminthes of the bank vole Clethrionomys glareolus. I. Patterns of co-occurrence. J. Anim. Ecol. 62: 221-229.

Hausdorf B, and Hennig C. 2007. Null model tests of clustering of species, negative co-occurrence patterns and nestedness in meta-communities. Oikos 116: 818-828.

Hirsch PE, Nechwatal J, and Fischer P. 2008. A previously undescribed set of Saprolegnia spp. in the invasive spiny-cheek crayfish (Orconectes limosus, Rafinesque). Fundam. Appl. Limnol. (Archiv. Hydrobiol.), 172: 161-165.

Ho WH, Hyde KD, Hodgkiss IJ, and Yanna A. 2001. Fungal communities on submerged wood from streams in Brunei, Hong Kong, and Malaysia. Mycol. Res. 105: 1492-1501.

Holdich DM, Reynolds JD, Souty-Grosset C, and Sibley PJ. 2010. A review of the ever increasing threat to European crayfish from non-indigenous crayfish species. Knowl. Manag. Aquat. Ec. (BFPP-Connaiss. Gest. P.), 394-395: 111.

Hu DM, Cai L, Chen H, Bahkali AH, and Hyde KD. 2010. Fungal diversity on submerged wood in a tropical stream and an artificial lake. Biodivers. Conserv., Doi: 10.1007/s10531010-9927-5.

Jain PK, Gupta VK, Misra AK, Gaur R, Bajpai V, and Issar S. 2011. Current status of Fusarium infection in human and animal. Asian J. Anim. Vet. Adv. 6: 201-227.

Keith P, and Allardi J. 1997. Bilan des introductions de poissons d'eau douce en France. Knowl. Manag. Aquat. Ec. (BFPPConnaiss. Gest. P.), 344-345: 181-191.

Kelly DW, Patterson RA, Townsend CR, Poulin R, and Tompkins DM. 2009. Parasite spillback: a neglected concept in invasion ecology? Ecology 90: 2047-2056.

Kozubíková E, Filipová L, Kozák P, Duuriš Z, Martín MP, Díeguez-Uribeondo J, Oidtmann B, and Petrusek A. 2010. Prevalence of the Crayfish Plague Pathogen Aphanomyces astaci in Invasive American Crayfishes in the Czech Republic. Conserv. Biol. 23: 1204-1213.

Krasnov BR, Stanko M, and Morand S. 2006. Are ectoparasite communities structured? Species co-occurrence, temporal variation and null models. J. Anim. Ecol. 75: 1330-1339.

Krasnov BR, Matthee S, Lareschi M, Korallo NP-Vinarskaya, and Vinarski MV. 2010. Co-occurrence of ectoparasites on rodent hosts: null model analyses of data from three continents. Oikos 119: 120-128.
Kuris AM, Hechinger RF, Shaw JC, Whitney KL, AguirreMacedo L, Boch CA, Dobson AP, Dunham EJ, Fredensborg BL, Huspeni TC, Lorda J, Mababa L, Mancini FT, Mora AB, Pickering M, Talhouk NL, Torchin ME, and Lafferty KD. 2008. Ecosystem energetic implications of parasite and freeliving biomass in three estuaries. Nature 454: 515-518.

Lehane M. 2005. The biology of blood-sucking in insects (2nd ed.). Cambridge University Press: $321 \mathrm{pp}$.

Lehsten V, and Harmand P. 2006. Null models for species cooccurrence patterns: assessing bias and minimum iteration number for the sequential swap. Ecography 29: 786-792.

Leveque C. 1997. Introductions de nouvelles éspèces de poissons dans les eaux douces tropicales: objectifs et consequences. Knowl. Manag. Aquat. Ec. (BFPP-Connaiss. Gest. P.), 344-345: 79-91.

Lodge DM, Taylor CA, Holdich DM, and Skurdal J. 2000. Nonindigenous crayfish threaten North American fresh-water biodiversity: lessons from Europe. Fisheries 25: 7-20.

McCoy ED, and Jr Heck KL. 1987. Some observations on the use of taxonomic similarity in large-scale biogeography. J. Biogeogr. 14: 79-87.

Mitchell CE. 2003.Trophic control of grassland production and biomass by pathogens. Ecol. Lett. 6: 147-155.

Patrick MJ. 1991. Distribution of enteric helminthes in Glaucomys volans L. (Sciuridae): a test for competition. Ecology 72: 755-758.

Patterson BD, and Atmar W. 1986. Nested subsets and the structure of insular mammalian faunas and archipelagos. Biol. J. Linn. Soc. 28: 65-82.

Pielou DP, and Pielou EC. 1968. Association among species of infrequent occurrence: the insect and spider fauna of Polyporus betulinus (Bulliard). Fries. J. Theor. Biol. 21: 202216.

Poulin R. 2007. Evolutionary ecology of parasites: from individuals to communities (2nd ed.). Princeton University Press: 332 pp.

Preston D, and Johnson P. 2010. Ecological Consequences of Parasitism. Nat. Ed. Knowl. 1: 39.

Rodríguez CF, Bécares E, Fernández-Aláez M, and FernándezAláez C. 2005. Loss of diversity and degradation of wetlands as a result of introducing exotic crayfish. Biol. Invasions 7: 75-85.

Rohde K. 2005. Nonequilibrium Ecology. Cambridge University Press, Cambridge: 223 pp.

Sanderson JG. 2000. Testing ecological patterns. Am. Sci. 88: 332-339.

Scalici M, and Gherardi F. 2007. Structure and dynamics of an invasive population of the red swamp crayfish (Procambarus clarkii) in a Mediterranean wetland. Hydrobiologia 583: 309-319.

Scalici M, and Gibertini G. 2007. Feeding habits of the crayfish Austropotamobius pallipes (Decapoda, Astacidae) in a brook of Latium (central Italy). Ital. J. Zool., 74: 157-168.

Scalici M, Belluscio A, and Gibertini G. 2008. Understanding the population structure and dynamics in threatened crayfish. J. Zool., Lond. 275: 160-171.

Scalici M, Chiesa S, and Gibertini G. 2009. Progress in understanding population structure and dynamics in inland water macrodecapods for biomonitoring programs. Atti del "IX Colloquium Crustacea Decapoda Mediterranea", Torino 
(Italy), 2-6 Settembre 2008: 169-187.

Schluter D. 1984. A variance test for detecting species associations, with some example applications. Ecology 65: 9981005.

Slater FM, and Rayner G. 1993. Austropotamobius pallipes in otter diet in the mid-Wye catchment of central Wales. Freshw. Crayfish. 9: 365-367.

Stone L, and Roberts A. 1990. The checkerboard score and species distributions. Oecologia 85: 74-79.

Taylor CA. 2002. Taxonomy and conservation of native crayfish stocks. In: D.M. Holdich (Ed.), Biology of freshwater crayfish. Blackwell Science, Oxford: 236-257 pp.

Tortorano AM, Prigitano A, Dho G, Esposto MC, Gianni C, Grancini A, Ossi C, and Viviani MA. 2008. Species distribution and in vitro antifungal susceptibility patterns of 75 clinical isolates of Fusarium from Northern Italy. Antimi- crob. Agents Chemother. 52: 2683-2685.

Usio N, and Townsend CR. 2004. Roles of crayfish: consequences of predation and bioturbation for stream invertebrates. Ecology 85: 807-822.

Vidal-Martinez VM, and Royal P. 2003. Spatial and temporal repeatability in parasite community structure of tropical fish hosts. Parasitology 127: 387-398.

Vogt G. 1999. Diseases of European freshwater crayfish, with particular emphasis on interspecific transmission of pathogens. In: F. Gherardi, and D.M. Holdich (Eds), Crayfish in Europe as alien species. How to make the best of a bad situation? A.A. Balkema, Rotterdam: 87-103.

Whitledge GW, and Rabeni CF. 1997. Energy sources and ecological role of crayfishes in an Ozark stream: insights from stable isotopes and gut analysis. Can. J. Fish. Aquat. Sci. 54: 2555-2563. 